\title{
An unusual presentation of pediatric acute lymphoblastic leukemia with parotid gland involvement and dactylitis
}

\author{
Parotid bezi tutulumu ve daktilit ile başvuran alışılmadık bir pediatrik akut \\ lenfoblastik lösemi vakası
}

\author{
Şule Ünal', Barış Kuşkonmaz'1, Yasemin Işı|k Balcl ${ }^{1}$, Bülent Cengiz², Murat Tuncer¹, Aytemiz Gürgey¹, \\ Erman Cilsal'3, Ayşe Gültekingili3, Fatma Gümrük1 \\ ${ }^{1}$ Division of Pediatric Hematology, Hacettepe University Faculty of Medicine, Ankara, Turkey \\ 2Division of Pediatric Infectious Diseases, Hacettepe University Faculty of Medicine, Ankara, Turkey \\ ${ }^{3}$ Department of Pediatrics, Hacettepe University Faculty of Medicine, Ankara, Turkey
}

\begin{abstract}
Mumps infection during the course of childhood acute lymphoblastic leukemia (ALL) treatment has been reported to have a mild course and this was related to the intrinsic low cytopathological effect of the virus, contrasting with the severe course of measles and Varicella zoster virus infections in immunocompromised patients. Herein, we present a three-yearold girl, who was previously vaccinated against mumps infection, admitted with bilateral parotid swelling, dactylitis and serum immunoglobulin M positivity for mumps infection and diagnosed to have ALL with bilateral persistent parotid involvement, inconsistent with mumps infection. Acute leukemia should be suspected during the atypical course of any disease during childhood. Besides, mumps infection at presentation of ALL, as similar to infection emerging during the period of the leukemia treatment, has a mild course. (Turk J Hematol 2010; 27: 117-9)
\end{abstract}

Key words: Mumps, parotitits, dactylitis, childhood, leukemia

Received: March 12, 2008

Accepted: April 8, 2009

\section{Özet}

Çocukluk çağı akut lenfoblastik lösemi (ALL) tedavisi boyunca geçirilebilecek kabakulak enfeksiyonunun, virusun düşük sitopatolojik etkileri nedeniyle, kızamık ve su çiçeği enfeksiyonlarının aksine daha hafif seyrettiğine dair raporlar bulunmaktadır. Daha önce kabakulak aşısı yapıımış olan üç yaşındaki kız hasta iki taraflı parotid bezinde şişlik ve daktilit nedeniyle başvurduğunda kabakulak IgM pozitifliği saptanmış ve ileri incelemesinde bilateral parotid infiltrasyonunun eşlik ettiği ALL tanısı konulmuştur. Çocukluk çağının atipik seyirli tüm hastalıklarında akut lösemi akılda tutulmalıdır. Aynı zamanda tedavi sırasında geçirilen kabakulak enfeksyonlarına benzer şekilde, ALL tanısı anında eşlik eden kabakulak enfeksiyonu da hafif seyretmektedir. (Turk J Hematol 2010; 27: 117-9)

Anahtar kelimeler: Kabakulak, parotit, daktilit, çocukluk çağı, lösemi 


\section{Introduction}

Acute parotitis is common in childhood, mostly associated with mumps infection and among the other causes there exist Staphylococcus aureus, human immunodeficiency virus (HIV), Mycobacterium tuberculosis, echovirus, parainfluenza (types 1 and 3), coxsackievirus A, adenovirus or cytomegalovirus [1]. Leukemia and lymphoma may cause enlargement in the salivary glands with or without the lacrimal gland involvement [2]. Primary benign and malign neoplasms of the parotitis gland are rare in childhood. Herein, we present a three-year-old girl, who was previously vaccinated against mumps infection, admitted with bilateral parotid swelling with immunoglobulin (lg) M positivity for mumps infection and diagnosed to have acute lymphoblastic leukemia (ALL) with bilateral parotid involvement. Previous data suggest that in malignant disease, the course of mumps is rarely severe and that the infection often remains subclinical, as in healthy children, contrasting with the severe course of measles and varicella [3]. However, data related to the mumps infection coinciding the presentation of childhood ALL is limited.

\section{Case report}

A three-year old girl presented with a seven day history of painful, fusiform swelling in digits of the hands and feet followed by bilateral swelling of the parotids. The personal history revealed vaccination for measles-mumps-rubella at 12-month of age, in an otherwise healthy children. Body weight and height were at 50th percentile. The physical examination revealed bilateral submandibular, posterior auricular and occipital lymphadenopathies, bilateral painful parotid swelling and dacytylitis. No abdominal tenderness and hepatosplenomegaly were detected. Menengeal irritation signs were absent. Enzyme immunoassay for mumps revealed lgM positivity and the dac- tylitis was evaluated as reactive arthritis. Erythrocyte sedimentation rate was $32 \mathrm{~mm} /$ hour, anti-nuclear antibody was negative and serum complement 3 and 4 levels were within normal ranges. However since parotid swelling and dactylitis persisted by the 10th day of the onset of symptoms, she was referred to Hacettepe University, Department of Pediatrics, Division of Pediatric Hematology. Informed consent was obtained from the patient. The parotid glands were painless, whereas digits were still painfully swollen at presentation to Division of Hematology (Figure 1). The hemogram was unremarkable except a normocytic anemia (hemoglobin: $9.2 \mathrm{~g} / \mathrm{dl}$, MCV: $82 \mathrm{fl}$; white blood cell count $7.9 \times 10^{9} / \mathrm{L}$, and platelet $124 \times 10^{9} / \mathrm{L}$ ) and peripheral blood smear exhibited $72 \%$ lymphocyte, $12 \%$ neutrophil, 7\% blast, 7\% monocyte and 2\% eosinophil. Serum lactate dehydrogenase (LDH) and uric acid were $631 \mathrm{IU} / \mathrm{L}$ and $5.6 \mathrm{mg} / \mathrm{dl}$, respectively. The hemoglobin electrophoresis ordered for investigation of dactylitis etiology and excluded $\mathrm{HbSS}$ and AS status. The bone marrow aspiration exhibited $100 \%$ blasts with L1 morphology according to FAB classification and immunophenotyping revealed a diagnosis of CALLA positive B-cell ALL. The ultrasonographic evaluation of parotids revealed bilaterally swollen gland with hypoechoic areas and hyperechoic septations. Apart from the $4 \times 4 \mathrm{~mm}$ and $6 \times 4 \mathrm{~mm}$ of size lymphadenopathies within both glands there was another one adjacent to the left parotid gland with 23x9 mm of size. Abdominal ultrasonography revealed a paraaortic lymphadenopathy of 9x6 mm size. Cytologic evaluation of the cerebrospinal fluid showed leukemic involvement of the central nervous system. By the 11th day of onset of symptoms the mumps serology was reordered and seroconversion to lgG was demonstrated and specific treatment for ALL with modified St: Jude Total XIII protocol was initiated [4]. Within 24 hours of the onset of $600 \mathrm{mg} / \mathrm{m}^{2} /$ day methylprednisolone treatment, the parotitis and swelling dactylitis resolved dramatically (Figure 2).
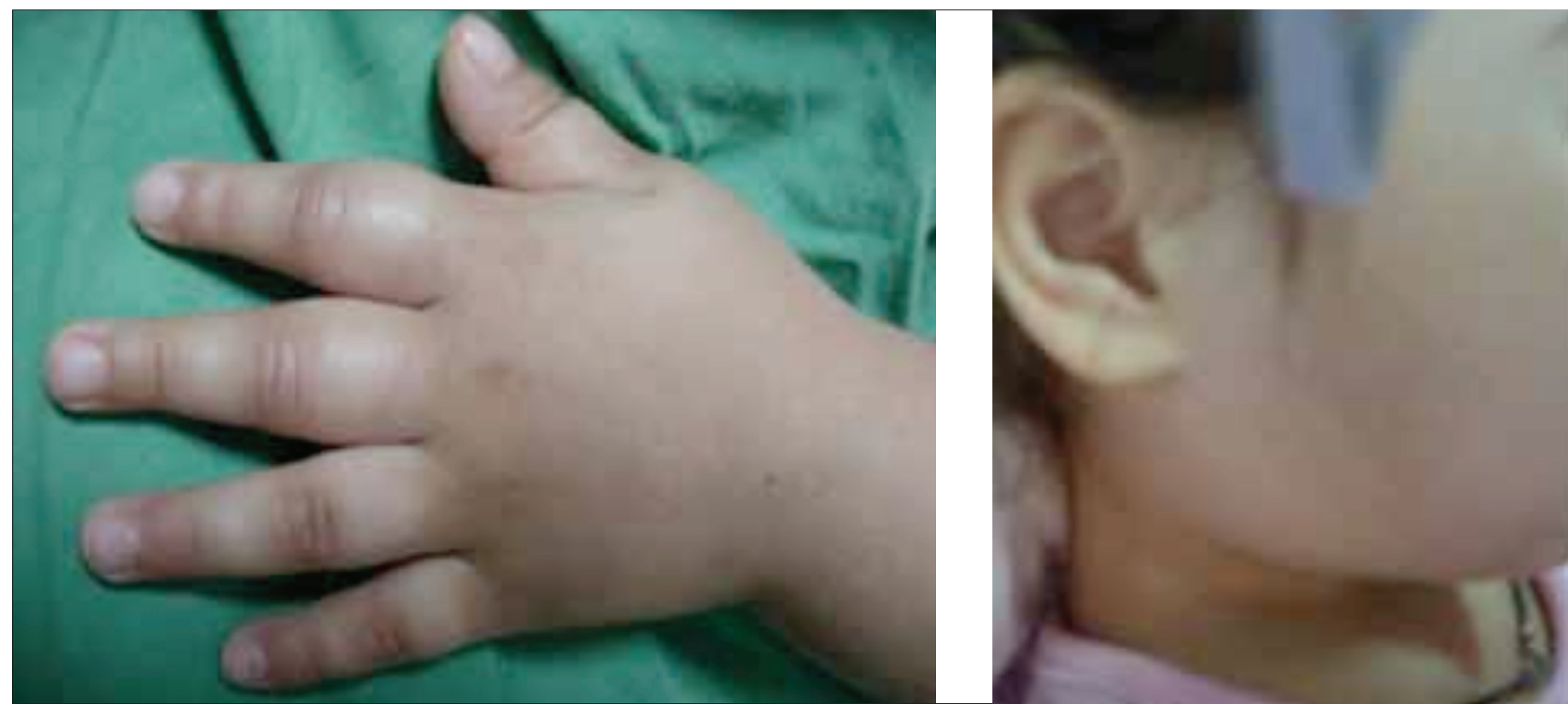

Figure 1. Dactylitis and parotid swelling prior to steroid treatment 

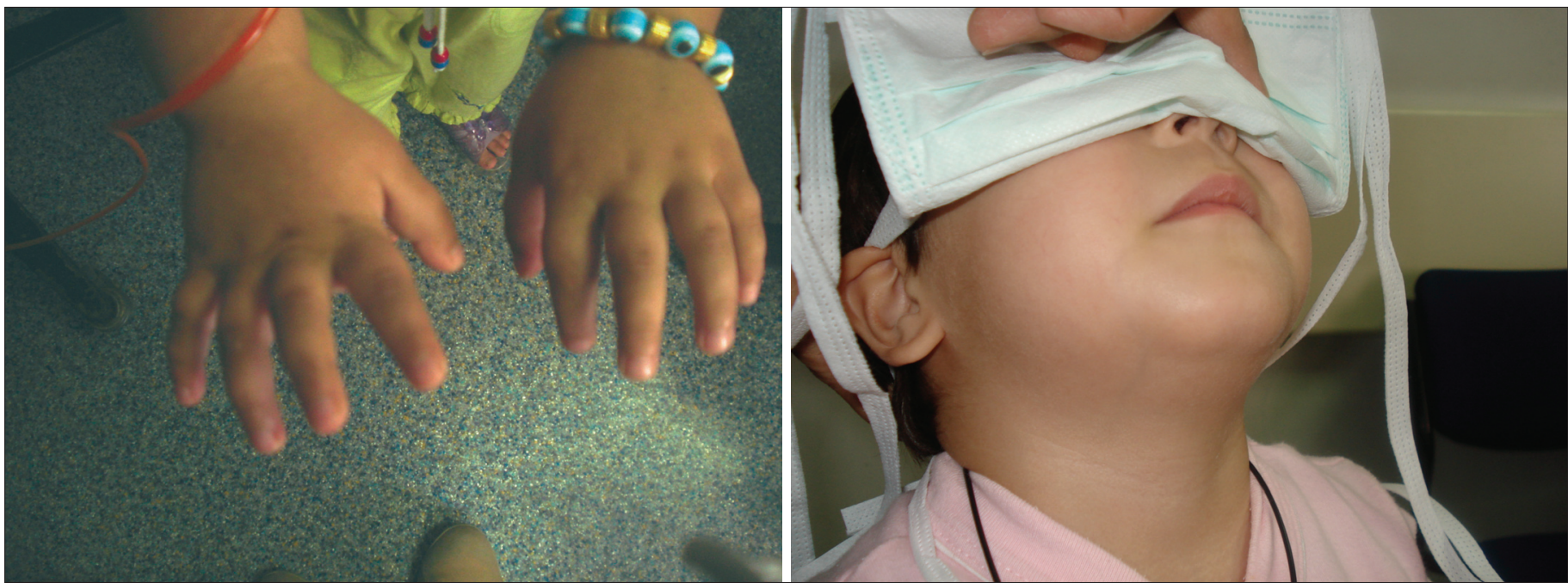

Figure 2. Disapperance of dactylitis and parotid swelling by the 24th hour of steroid treatment

\section{Discussion}

Mumps is a systemic illness caused by the paramyxovirus and the incidence has decreased substantially with the introduction of vaccination [5]. Mumps infection during the course of childhood ALL has been reported to have a mild course and this was related to the intrinsic low cytopathological effect of the virus, contrasting with the severe course of measles and Varicella zoster virus infections in immunocompromised patients [3]. On the other hand, up to our knowledge, this is the first report of mumps infection coincidentally diagnosed at presentation of childhood ALL. Although, mumps infection is common in childhood, the persistent swelling of parotids by the 10th day of onset of symptoms is quite uncommon and surged a possibility of a malignant infiltration of the gland, which was confirmed by the bone marrow examination.

Another interesting finding of the patient was the associated dactylitis, which is quite uncommon for a patient with mumps infection. Dactylitis can occur in seronegative arthropathies, such as psoriatic arthritis and ankylosing spondylitis, in sicklecell disease as result of a vasoocclusive crisis with bone infarcts, and in infectious conditions including tuberculosis and leprosy [6]. The most common presenting feature in patients with musculoskeletal complaints who were diagnosed to have an underlying malignancy was monoarthritis, involving the larger joints such as the elbows, knees or ankles. Juvenile idiopathic arthritis was the most frequent provisional diagnosis [7]. A malignancy should always be excluded in children with musculoskeletal symptoms, especially when the clinical pattern is not characteristic of a specific rheumatic disease. A simultaneous presence of high LDH even with normal blood cell counts, should lead to additional investigations, as in the present case.

The mumps vaccine induces antibody in $96.9 \%$ of seronegative recipients and has 95\% protective effect in immunocompotent children [5]. It was previously reported that the seropositivity rates for measles and mumps-specific immunoglobulin G were $\geq 90 \%$, while the seropositivity rate for rubella was $85 \%$ in 39 previously vaccinated children before administration of chemotherapy for acute leukemia. After treatment, rates of seropositivity for mumps antibody was reported to be as low as $18 \%$ in previously vaccinated children [8]. The immunocompromised state of the leukemic patient at diagnosis and during treatment might prone these previously vaccinated children to infection.

In conclusion, acute lymphoblastic leukemia should be suspected during the atypical course of any disease during childhood. Besides, mumps infection at presentation of ALL has a mild course, like the infection that emerge during the period of leukemia treatment.

\section{Conflict of interest}

No author of this paper has a conflict of interest, including specific financial interests, relationships, and/or affiliations relevant to the subject matter or materials included in this manuscript.

\section{References}

1. McQuone SJ. Acute viral and bacterial infections of the salivary glands. Otolaryngol Clin North Am 1999;32:793-811.

2. Morgan WS, Castleman B. A clinicopathologic study of Mikulicz's disease. Am J Pathol 1953;29:471-503.

3. de Boer AW, de Vaan GA. Mild course of mumps in patients with acute lymphoblastic leukaemia. Eur J Pediatr. 1989; 148: 618-9.

4. Gurgey A, Yetgin S, Cetin M, Gümrük F, Tuncer AM, Tunçbilek E, Hiçsönmez G. Acute lymphoblastic leukemia in infants. Turk J Pediatr 2004; 46:115-9.

5. Plotkin SA. Mumps vaccine. In: Vaccines. Plotkin SA, Orenstein WA (eds). Philadelphia, Saunders, 2004:441-70.

6. Rothschild BM, Pingitore C, Eaton M. Dactylitis. Implications for clinical practice. Semin Arthritis Rheum 1998;28:41-7.

7. Simonini G, Calabri GB, Falcini F. Incidence of occult cancer in children presenting with musculoskeletal symptoms: a 10-year survey in a pediatric rheumatology unit.Semin Arthritis 2000;29:348-59.

8. Feldman S, Andrew M, Norris M, Mclntyre B, lyer R. Decline in rates of seropositivity for measles, mumps, and rubella antibodies among previously immunized children treated for acute leukemia.Clin Infect Dis 1998;27:388-90. 